\title{
Severe, Malignant Acanthosis Nigricans Associated with Adenocarcinoma of the Endometrium in a Young Obese Female
}

\author{
Jacqueline Deen $^{\mathrm{a}} \quad$ Thomas Moloney $^{\mathrm{b}} \quad$ David Burdon-Jones $^{\mathrm{a}}$ \\ ${ }^{a}$ Department of Dermatology, Mater Misericordiae Hospital, Brisbane, QLD, Australia; \\ ${ }^{\mathrm{b}}$ Princess Alexandra Hospital, Brisbane, QLD, Australia
}

\section{Keywords}

Malignant acanthosis nigricans · Benign acanthosis nigricans · Endometrial adenocarcinoma

\begin{abstract}
Acanthosis nigricans (AN) is a dermatopathy associated with insulin-resistance, drugs, endocrine disorders, chromosomal abnormalities (benign AN), and neoplasia (malignant AN). Malignant AN (MAN) is a rare paraneoplastic skin syndrome most commonly associated with gastric adenocarcinoma and other intra-abdominal malignancies. We report the case of a 28 year-old female with AN associated with obesity, insulin resistance, and endometrial adenocarcinoma. Although rare, MAN is often an initial sign of malignancy and must trigger extensive investigation, particularly in patients with sudden development of possibly paraneoplastic dermatoses or in patients diagnosed with benign AN with any atypical features.
\end{abstract}

(c) 2017 The Author(s)

Published by S. Karger AG, Basel 


\section{Introduction}

Acanthosis nigricans (AN) is a cutaneous eruption characterised by symmetric velvety hyperpigmented, verrucous plaques of the intertriginous surfaces of the axilla, neck, inframammary, and mucocutaneous regions and can be classified as benign or malignant [1]. Benign cases are typically associated with obesity and insulin resistance, while malignant AN (MAN) has been associated with intra-abdominal malignancies including gastric, oeseophageal, pancreatic, and hepatic duct adenocarcinomas and also rarely gynaecological malignancies [1]. We present the case of a 28-year-old female with AN associated with a combination of benign and malignant aetiologies. She initially presented with benign features of obesity and insulin resistance; however, the progressive nature of her AN later manifested as a paraneoplastic dermatosis of endometrial adenocarcinoma.

\section{Case Report}

A 28-year-old morbidly obese female was referred to the dermatology clinic with a pruritic, hyperpigmented facial eruption. Similar hyperpigmentation was present on her neck, axillae, and forearms. The patient reported this profound increase in pigmentation occurred after she gained approximately 30-40 kg over the last 8 years since the birth of her first child. She also reported that this had dramatically worsened in the last 12 months. She had been using intermittent topical corticosteroids for the last 5 years with minimal effect.

The patient reported a history of irregular menstrual cycles with associated menorrhagia. She had been feeling otherwise well with no constitutional symptoms and denied any alteration in her bowel habit, melaena, or per rectal blood loss. There were no genitourinary symptoms.

Her background medical issues included morbid obesity, sleep apnoea, and a recent diagnosis of bilateral cataracts, requiring surgery. She reported a positive family history of diabetes and breast cancer but denied any personal history of diabetes or malignancy.

The patient did not take any regular medications and had no known allergies. She was a smoker and consumed alcohol occasionally. She was currently unemployed and lived with her 7-year-old daughter.

On examination, the patient was obese with a BMI of 49. There was widespread hyperpigmentation with marked skin thickening of her axillae, arms, abdominal folds, face, and ears (Fig. 1, Fig. 2). There was sparing of the nose and vermillion border of her upper lip. She had macrocephaly with a prominent nose, round face and a "buffalo hump". There were no skin tags or oral and tongue changes. Examination of the scalp revealed cerebriform folding of the skin consistent with cutis verticis gyrata.

Her cardiorespiratory and abdominal examinations were unremarkable. There was no adenopathy. Multiple punch biopsies were performed which showed psoriasiform hyperplasia, moderate dermal fibrosis, and superficial to mid-perivascular and perifollicular inflammation consistent with AN.

Given the extensive presentation of AN, the patient subsequently underwent extensive investigations for potential endocrinopathies and to exclude underlying malignancy. She had an oral glucose tolerance test, which revealed severe insulin resistance. Serological investi- 
gation showed a mild polycythaemia with a haemoglobin level of $163 \mathrm{~g} / \mathrm{L}$, with an otherwise normal full blood count and iron studies. She had an elevated ALT of $49 \mathrm{U} / \mathrm{L}$, but other liver function tests were normal. Total cholesterol was elevated at $5.5 \mathrm{mmol} / \mathrm{L}$ with an LDL of $4.05 \mathrm{mmol} / \mathrm{L}$, and triglycerides were $2.1 \mathrm{mmol} / \mathrm{L}$.

In terms of investigation for endocrinopathy, she had an undetectable growth hormone, a low IGF-1 at $7 \mathrm{nmol} / \mathrm{L}$, a low 24-h urinary free cortisol and normal thyroid function tests. FSH and LH were significantly depressed, and she had elevated testosterone and free androgen index.

The patient was referred to gynaecology where she underwent a further panel of investigations. A hysteroscopy with dilation and curettage and Mirena insertion was performed. A CT of the chest, abdomen, and pelvis revealed no abnormalities, and tumour markers were also unremarkable, with a nonsignificant CA 125 level of $16 \mathrm{kU} / \mathrm{L}$. Histology of the curettings confirmed grade 1 adenocarcinoma of the endometrium, and the patient was scheduled for a formal hysteroscopy/dilation and curettage in 3 months time. Additionally, the patient was referred to dietetics for education regarding diet and weight reduction and was referred for a formal sleep study to investigate her sleep apnoea.

\section{Discussion}

AN is a cutaneous eruption characterised by symmetric velvety hyperpigmented, verrucous plaques of the intertriginous surfaces of the axilla, neck, inframammary, and mucocutaneous regions [1]. AN is a cutaneous marker of systemic diseases, which can be classified into benign and malignant forms. Benign AN can be familial, drug induced, or correlated with a variety of endocrinopathies, notably insulin resistance and obesity. The benign form is usually insidious in onset and less widespread in distribution. In contrast, MAN is most commonly related with intra-abdominal malignancies and very rarely gynecological carcinomas [1]. MAN is usually rapid in onset, widespread in distribution, and sometimes has facial involvement. It can also be associated with skin tags, multiple seborrheic keratosis (the sign of Leser-Trelat), or ridged velvety lesions on the palms (tripe palms) [1].

The pathophysiology of AN is unknown but thought to involve one or more stimulating factors, which ultimately cause the epidermal proliferation that is seen on histopathological section. In MAN, the proposed etiology is thought to involve tumour secretion of a peptide with growth factor properties - potentially transforming growth factor-alpha, insulin growth factor-1, or melanocyte-stimulating hormone alpha [1]. Histopathology of biopsies typically reveals papillomatosis, hyperkeratosis, and acanthosis and an increased number of basal melanocytes. Interestingly, MAN tends to follow the course of an underlying malignancy often spreading with tumour progression, then regressing with successful therapy. Recurrences of AN occurring with cancer recurrence or metastases have also been reported.

Gynaecological malignancies have rarely been reported with MAN including 6 cases of ovarian cancer, 5 cases of endometrial carcinoma, and 2 cases of cervical carcinoma (Table 1). These patients presented with MAN between the ages of 47-83 years, with an average age of 59.5 years. Tripe palms and MAN occurring in the axillae are the most common sites occurring in 77 and $85 \%$ of the cases, respectively. 
Compared to previous cases, our case is of particular interest because our patient's AN could be due to a combination of both benign and malignant aetiologies - which has not previously been reported. The patient initially had features consistent with a benign form including an insidious onset at a young age associated with insulin resistance and obesity. This was then followed recently with a rapid year-long deterioration of the condition associated with widespread hyperpigmentation and hyperkeratosis involving the axillae, arms, abdominal folds, ears, and the face - suggestive of MAN. Compared to previous cases of gynaecological malignancy associated with MAN, our case also presented at a much younger age and also at an unusually young age for the diagnosis of endometrial carcinoma.

Our patient also had cutis verticis gyrata, a rare clinical finding with cerebriform thickening of the scalp, manifesting as deep furrows and convoluted ridges. This condition is commonly due to systemic disease, inflammatory dermatoses, underlying nevoid abnormalities, or trauma [2]. The condition has rarely been described in association with malignancy, and although the cause of our patient's cutis verticis gyrata is not clear, the fact that it appeared in association with this patient's endometrial carcinoma is of note.

Although rare, MAN is often an initial sign of malignancy and should trigger extensive investigation. This should include a review of systems including gastrointestinal symptoms, constitutional symptoms and a detailed gynaecological history. Initial investigations should include routine blood tests, chest X-ray, and also possible referral for endoscopy, breast examination, Pap smear, pelvic examination/ultrasound, and other abdominal imaging if relevant. In patients diagnosed with benign $\mathrm{AN}$, any atypical features or poor response to treatment should also raise the possibility of underlying malignancy. This was depicted by the dual aetiologies in our patient and shows that physicians should have a low threshold for thorough investigation if malignancy is a possibility.

\section{Statement of Ethics}

The authors state that the patients gave their informed consent. The research complies with all ethical guidelines for human studies.

\section{Disclosure Statement}

The authors have no conflicts of interest to disclose.

\section{References}

1 Mekhail TM, Markman M: Acanthosis nigricans with endometrial carcinoma: case report and review of the literature. Gynecol Oncol 2002;84:332-334.

-2 Ross J, Tompkins M: Cutis veriticis gyrata as a marker of internal malignancy. Arch Dermatol 1989;125:434-435.

3 Curth HO, Tovell HM, Janovski N: Malignant acanthosis nigricans associated with endometrial adenocarcinoma. Bull Sloane Hosp Women Columbia Presbyt Med 1962;8:141-146. 


\section{Case Reports in Dermatology}

\begin{tabular}{l|l} 
DOI: $10.1159 / 000456652$ & (C) 2017 The Author(s). Published by S. Karger AG, Basel
\end{tabular} www.karger.com/cde

Deen et al.: Severe, Malignant Acanthosis Nigricans Associated with Adenocarcinoma of the Endometrium in a Young Obese Female

4 Mikhail GR, Fachnie DM, Drukker BH, Farah R, Allen HM: Generalized malignant acanthosis nigricans. Arch Dermatol 1979;115:201-202.

-5 Requena L, Aguilar A, Renedo G, Martín L, Piqué E, Fariña MC, Escalonilla P: Tripe palms: a cutaneous marker of internal malignancy. J Dermatol 1995;22:492-495.

6 Gorisek B, Krajnc I, Rems D, Kuhelj J: Malignant acanthosis nigricans and tripe palms in a patient with endometrial adenocarcinoma - a case report and review of the literature. Gynecol Oncol 1997;65:539542.

7 Tsai YJ, Tsai YJ, Chuan MT, Hu SL: The Combination of tripe palms, acanthosis nigricans and florid cutaneous papillomatosis in a patient with metastatic cervical cancer. Dermatol Sinica 2004;22:142147.

8 Longshore SJ, Taylor JS, Kennedy A, Nurko S: Malignant acanthosis nigricans and endometrioid adenocarcinoma of the parametrium: the search for malignancy. J Am Acad Dermatol 2003;49:541543.

-9 Kebria MM, Belinson J, Kim R, Mekhail TM: Malignant acanthosis nigricans, tripe palms and the sign of Leser-Tre'lat, a hint to the diagnosis of early stage ovarian cancer: a case report and review of the literature. Gynecol Oncol 2006;101:353-355.

$\rightarrow 10$ Oh CW, Yoon J, Kim CY: Malignant acanthosis nigricans associated with ovarian cancer. Case Rep Dermatol 2010;2:103-109.

11 Singh SK, Raj T: A rare case of malignant acanthosis nigricans in a lady with ovarian cancer. Indian Dermatol Online J 2013;4:125-127.

12 Chu HW, Li JM, Chen GF, Ma JY: Oral malignant acanthosis nigricans associated with endometrial adenocarcinoma. Int J Oral Sci 2014;6:247-249.

13 Garzitto A, Ricceri F, Pescitelli L, Tripo L, Prignano F: Vitiligo masks malignant acanthosis nigricans in a woman with ovarian cancer. Int J Dermatol 2015;54:1300-1302.

14 Dingley ER, Marten RH: Adenocarcinoma of the ovary presenting as acanthosis nigricans. J Obstet Gynaecol Br Emp 1957;64:898-900. 


\section{Case Reports in Dermatology}

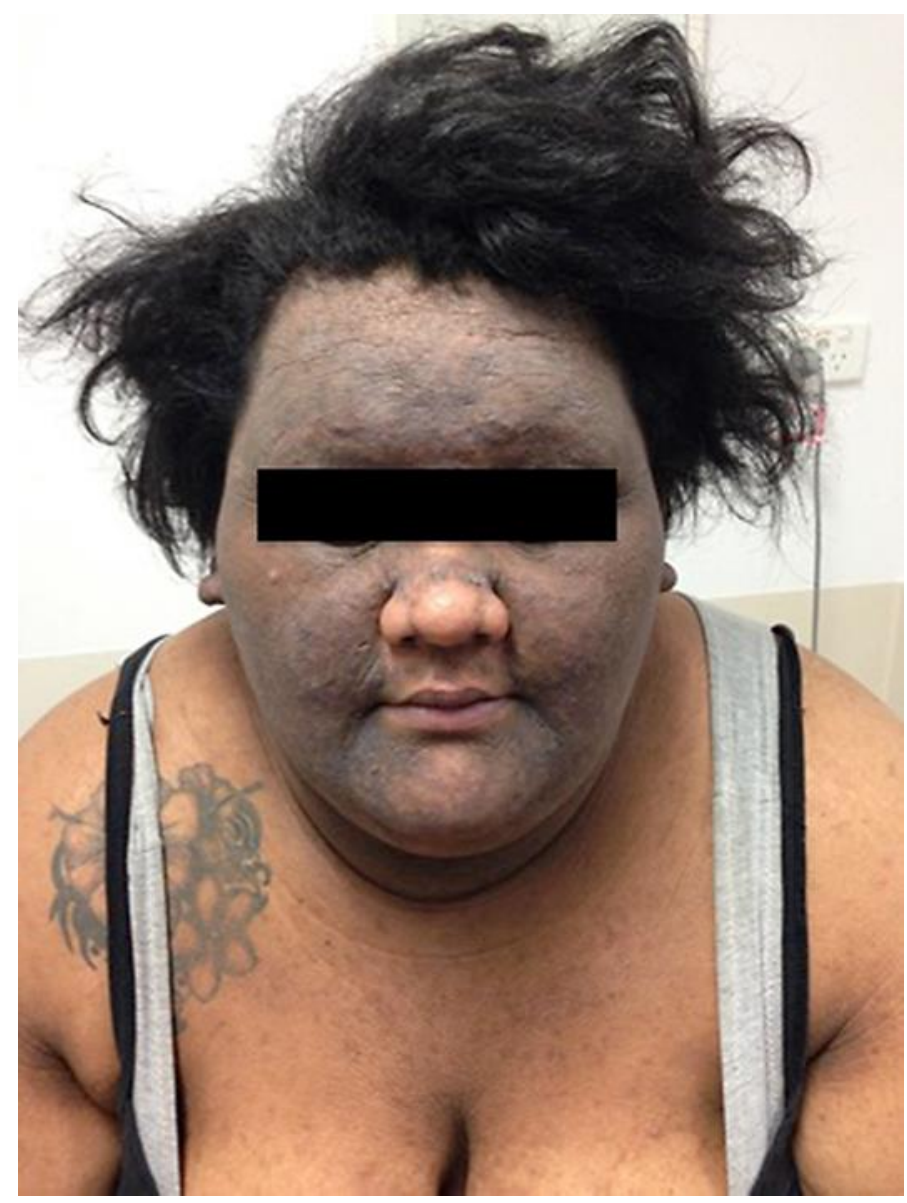

Fig. 1. Facial distribution of the patient's MAN. 


\section{Case Reports in Dermatology}

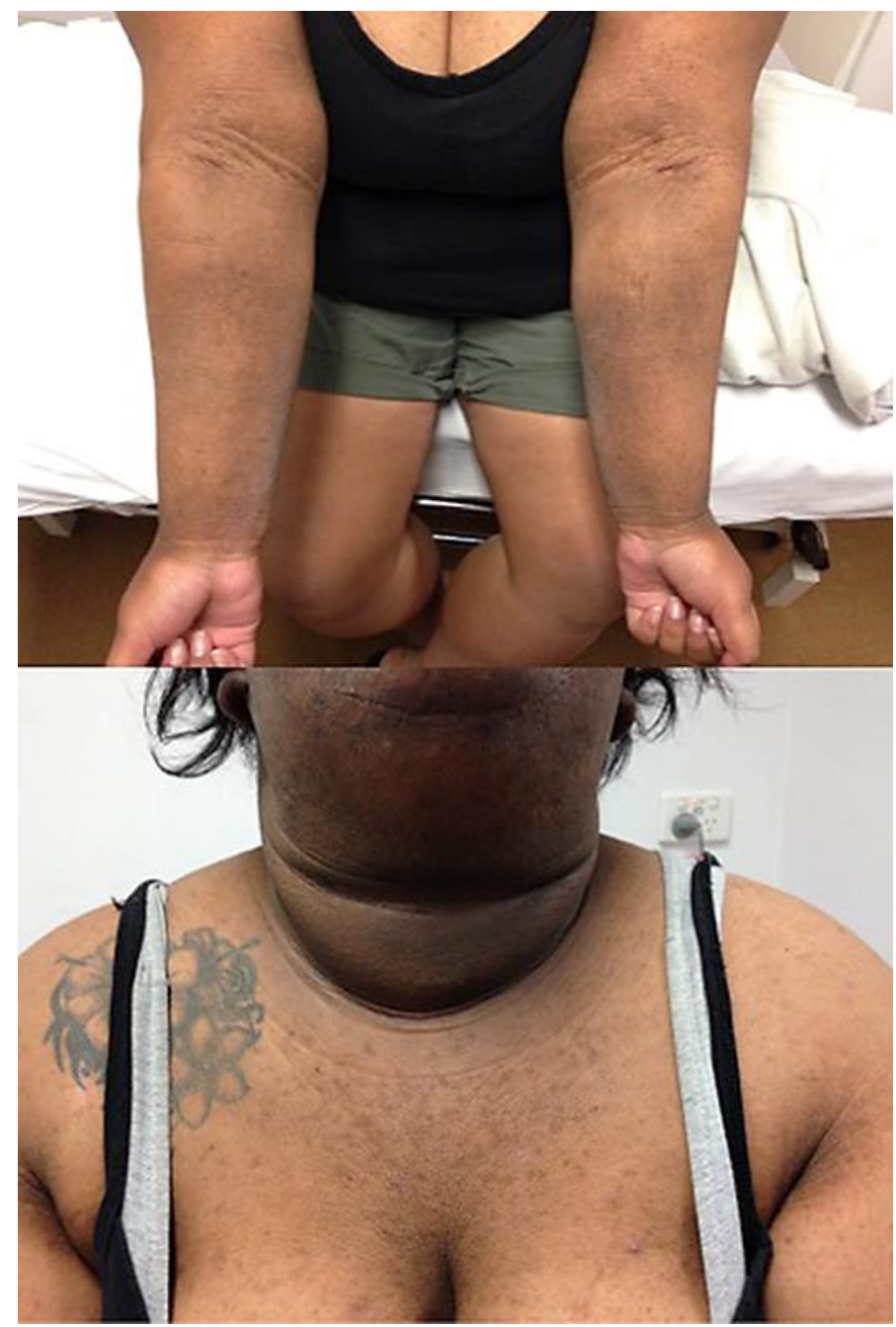

Fig. 2. Distribution of the patient's MAN. 
Deen et al.: Severe, Malignant Acanthosis Nigricans Associated with Adenocarcinoma of the Endometrium in a Young Obese Female

Table 1. Previously reported cases of malignant acanthosis nigricans (MAN) associated with gynaecological malignancies

\begin{tabular}{|c|c|c|c|c|}
\hline $\begin{array}{l}\text { First author [ref.], } \\
\text { year }\end{array}$ & $\begin{array}{l}\text { Patient } \\
\text { age, years, } \\
\text { gender }\end{array}$ & Presentation & MAN distribution & Malignancy \\
\hline $\begin{array}{l}\text { Dingley } \\
{[14], 1957}\end{array}$ & $56 / \mathrm{F}$ & $\begin{array}{l}\text { Warts presenting on arms, legs, and } \\
\text { trunk; dry/sore tongue and cheeks; } \\
\text { no B symptoms }\end{array}$ & $\begin{array}{l}\text { Arms, legs, trunk, face, oral, palms, soles, } \\
\text { anus, groin, axillae }\end{array}$ & $\begin{array}{l}\text { Ovarian } \\
\text { adenocarcinoma }\end{array}$ \\
\hline $\begin{array}{l}\text { Curth } \\
{[3], 1962}\end{array}$ & $55 / F$ & $\begin{array}{l}\text { Vaginal discharge, postmenopausal } \\
\text { bleeding }\end{array}$ & $\begin{array}{l}\text { Dorsa of hands, forearms, back, trunk, legs, } \\
\text { umbilicus, axillae, } \\
\text { perianal and vulvar }\end{array}$ & $\begin{array}{l}\text { Endometrial } \\
\text { carcinoma }\end{array}$ \\
\hline $\begin{array}{l}\text { Mikhail } \\
{[4], 1979}\end{array}$ & $58 / \mathrm{F}$ & Condylomata of the perineum & $\begin{array}{l}\text { Face, oral involvement, palms and soles, } \\
\text { perineal region, } \\
\text { inframammary region, vulva, anus, gluteal } \\
\text { cleft, upper thigh, axillae }\end{array}$ & $\begin{array}{l}\text { Cervical } \\
\text { squamous cell } \\
\text { carcinoma }\end{array}$ \\
\hline $\begin{array}{l}\text { Requena } \\
{[5], 1995}\end{array}$ & $83 / \mathrm{F}$ & $\begin{array}{l}8 \text { months of increasing } \\
\text { hyperkeratosis of palms, } 5 \text { months of } \\
\text { anorexia and weight loss, and } 3 \\
\text { months of night sweats }\end{array}$ & Palms, dorsum of hands, axillae and groin & $\begin{array}{l}\text { Ovarian } \\
\text { carcinoma }\end{array}$ \\
\hline $\begin{array}{l}\text { Gorisek } \\
{[6], 1997}\end{array}$ & $54 / \mathrm{F}$ & Postmenopausal menorrhagia & $\begin{array}{l}\text { Tripe palms, dorsal neck, axilla, infram- } \\
\text { ammary region, abdominal folds, inguinal } \\
\text { and forearms; oral involvement also }\end{array}$ & $\begin{array}{l}\text { Endometrial } \\
\text { adenocarcinoma }\end{array}$ \\
\hline $\begin{array}{l}\text { Mekhail } \\
{[1], 2002}\end{array}$ & $69 / \mathrm{F}$ & Hypothyroidism, obesity & $\begin{array}{l}\text { Tripe palms, face, neck, axillae, groin and } \\
\text { inframammary region }\end{array}$ & $\begin{array}{l}\text { Endometrial } \\
\text { adenocarcinoma }\end{array}$ \\
\hline $\begin{array}{l}\text { Tsai } \\
\text { [7], } 2004\end{array}$ & $55 / F$ & Cervical cancer & $\begin{array}{l}\text { Palms, dorsum of hand, soles, thighs, neck, } \\
\text { axillar, waist }\end{array}$ & Cervical cancer \\
\hline $\begin{array}{l}\text { Longshore } \\
\text { [8], } 2003\end{array}$ & $69 / \mathrm{F}$ & Anorexia, weight loss & $\begin{array}{l}\text { Face, axillae, groin, hands, soles, infram- } \\
\text { ammary folds }\end{array}$ & $\begin{array}{l}\text { Endometrial } \\
\text { adenocarcinoma }\end{array}$ \\
\hline $\begin{array}{l}\text { Kebria } \\
{[9], 2006}\end{array}$ & $52 / \mathrm{F}$ & Weight loss & $\begin{array}{l}\text { Neck, axillae, inframammary, palms and } \\
\text { soles, groin and oral involvement, tripe } \\
\text { palms }\end{array}$ & $\begin{array}{l}\text { Ovarian } \\
\text { adenocarcinoma }\end{array}$ \\
\hline $\begin{array}{l}\text { Oh } \\
{[10], 2010}\end{array}$ & $57 / F$ & No B symptoms & $\begin{array}{l}\text { Neck, axillae, groin, oral, forearms, palms } \\
\text { and soles }\end{array}$ & $\begin{array}{l}\text { Ovarian } \\
\text { adenocarcinoma }\end{array}$ \\
\hline $\begin{array}{l}\text { Singh } \\
{[11], 2013}\end{array}$ & $47 / \mathrm{F}$ & $\begin{array}{l}\text { Fatigue, weight loss, and night sweats } \\
\text { for } 8 \text { months }\end{array}$ & Face and body & $\begin{array}{l}\text { Ovarian } \\
\text { adenocarcinoma }\end{array}$ \\
\hline $\begin{array}{l}\text { Chu } \\
{[12], 2014}\end{array}$ & $59 / F$ & $\begin{array}{l}\text { Previous endometrial } \\
\text { carcinoma ( } 9 \text { years before) }\end{array}$ & $\begin{array}{l}\text { Face, elbows, pudendum, groin, axillae, } \\
\text { nipples }\end{array}$ & $\begin{array}{l}\text { Endometrial } \\
\text { carcinoma }\end{array}$ \\
\hline $\begin{array}{l}\text { Garzitto } \\
{[13], 2015}\end{array}$ & $60 / \mathrm{F}$ & $\begin{array}{l}\text { Vitiligo and AN; otherwise well, no B } \\
\text { symptoms }\end{array}$ & $\begin{array}{l}\text { Axillary, inframammary region, inguinal, } \\
\text { genital, perioral, tripe palms }\end{array}$ & $\begin{array}{l}\text { Ovarian } \\
\text { adenocarcinoma }\end{array}$ \\
\hline
\end{tabular}

